\title{
Ogólnopolska konferencja naukowa „Militaria w edukacji historycznej” - Rozewie 2014 r.
}

$\mathrm{W}$ dniach 24-26 września 2014 r. odbyła się na Rozewiu konferencja „Militaria w edukacji historycznej” zorganizowana przez Wydział Nauk Humanistycznych i Społecznych Akademii Marynarki Wojennej w Gdyni. Na zaproszenie organizatorów odpowiedziały wszystkie ważniejsze ośrodki akademickie w kraju, w których historia wojskowa jest realizowana jako kierunek studiów. Wolę osobistego uczestnictwa potwierdziło 46 osób.

Dotrzymanie przez uczestników konferencji terminów narzuconych przez organizatorów (przez m.in. nadesłanie materiałów mających stanowić podstawę przygotowywanej publikacji) pozwoliło organizatorom na stworzenie ostatecznej wersji programu, który łączył ze sobą sprawy merytoryczne $\mathrm{z}$ elementami rekreacyjnymi. Organizatorzy nie czynili bowiem w tej ostatniej materii żadnych ograniczeń, wręcz przeciwnie, zachęcając w tzw. czasie wolnym do skorzystania z uroków jesiennego morza i wybrzeża.

Uczestników konferencji poproszono o przygotowanie swoich wystąpień na tyle wcześnie, by można było to spotkanie naukowe poprowadzić w sposób odbiegający od standardowego. W zamyśle bowiem organizatorów konferencji, przy akceptacji Rady Naukowej, nastawiono się na dyskusję problemową w oparciu o wydaną publikację, odchodząc od tradycyjnego wygłaszania opublikowanych już referatów. Dlatego też organizatorom zależało na dotrzymaniu terminów harmonogramu przygotowań przedkonferencyjnych. Wszystkie nadesłane materiały przygotowano do druku z uwzględnieniem wymogów redakcyjnych. 
Pierwszy tom, pt. O użyteczności wiedzy wojskowej, ukazał się pod redakcją naukową dr. Andrzeja Drzewieckiego, a tom drugi, pt. Przeszłości nie można zrekonstruować..., pod redakcją naukową dr. Andrzeja Drzewieckiego i dr. Łukasza Różyckiego. Dwutomowa publikacja pod wspólnym tytułem Militaria $w$ edukacji historycznej została zrecenzowana przez prof. dr. hab. Wiesława Wróblewskiego i dr. hab. Dariusza Łukasiewicza, prof. PAN. W efekcie z początkiem września udało się przesłać uczestnikom egzemplarze gotowej publikacji, z nadzieją i przekonaniem, że będzie ona inspiracją do wielowątkowej dyskusji.

Konferencję rozpoczęto od wystąpienia przewodniczącego komitetu organizacyjnego, dr. Andrzeja Drzewieckiego, który witając uczestników, wyraził przekonanie, że ustalenia oraz wyniki badań, złożone do dwutomowej publikacji oraz dyskusja merytoryczna w zespołach problemowych, staną się ważnym uzupełnieniem istniejącego stanu wiedzy i spowodują, że historia wojskowa znajdzie swoich licznych zwolenników, a militaria będą nadal pasjonować i przykuwać uwagę różnych gremiów i ośrodków badawczych. Głos zabrali również: prorektor ds. kształcenia AMW dr hab. Jerzy Kojkoł, prof. AMW, który przywitał zgromadzonych w imieniu władz uczelni, oraz obecny na inauguracji wójt Gminy Puck Tadeusz Puszkarczuk.

Zgodnie z przyjętymi założeniami, w głównym panelu zrezygnowano $\mathrm{z}$ prezentowania referatów. Tezy dyskusyjne przewidziane w sesji plenarnej przedstawiło sześciu profesorów reprezentujących różne ośrodki akademickie. Jako pierwszy zabrał głos prof. Marin Mroczko, który zajął się problematyką Pomorza w polskiej myśli politycznej przełomu XIX i XX w. Profesor podkreślił w swoim wystąpieniu, że Pomorze w tym okresie zajmowało ważne miejsce $\mathrm{w}$ polskiej dyspucie politycznej. Wszystkie główne kierunki polityczne przejawiały duże zainteresowanie tym obszarem, a politycy i publicyści poświęcali wiele uwagi sprawom morskim i pomorskim. Swoimi wystąpieniami ostrzegali przed niemieckim rewizjonizmem. Z kolei prof. Karol Olejnik poruszył kwestie historii i historyków wojskowości wobec współczesnych wyzwań dydaktycznych i badawczych. Zauważył, że historia wojskowości może być przydatna w szeroko rozumianej dydaktyce, tj. w szkole, w pracy oświatowej w wojsku, w publicystyce, w tzw. wychowaniu patriotycznym, podczas popularyzacji wiedzy etc., jedynie przy założeniu pewnych rygorów, które powinny być możliwie ściśle przestrzegane. Przekaz powinien być wszechstronny, w najwyższym stopniu obiektywny, przekazywane określone quantum wiedzy powinno dążyć do wyeliminowania tzw. białych plam, wydarzenia z przeszłości należy odnosić do czasów współczesnych, także tych 
najnowszych. Trzecim prelegentem był prof. Andrzej Makowski, który postawił pytanie: czy można mówić o edukacyjnych wartościach wojen? Wyraził m.in. pogląd, że trudno oczekiwać, iż większość społeczeństwa będzie pilnie studiowała historię wojen, zarazem jednak warto we współczesnym świecie zauważyć edukacyjny charakter takich studiów. Nadmienił, że skoro dzisiejszy świat jest oparty na wiedzy i informacji, warto $\mathrm{w}$ to inwestować, gdyż odpowiedni zasób wiedzy pozwala na identyfikację wyzwań współczesnej cywilizacji. Brak odpowiedniej wiedzy zaowocuje bezradnością i oczekiwaniem, że ktoś za nas rozwiąże obecne i niełatwe problemy. Kolejnym dyskutantem była prof. Danuta Kisielewicz z tematem: „Obozy jenieckie i koncentracyjne - jak edukować, by zachować powagę miejsca i rzetelność przekazu historycznego?". Podkreśliła w swoim wystąpieniu, że jednymi z ważnych instytucji przekazu historycznego są muzea martyrologiczne, zajmujące się upamiętnianiem miejsc pamięci związanych z przetrzymywaniem i męczeństwem ludności cywilnej i żołnierzy w latach II wojny światowej. Muzea te, umożliwiając zwiedzanie obiektów muzealnych, udostępniając swe zbiory, organizująca wystawy i upowszechniając wyniki swych badań naukowych, oddziałują na kulturę historyczną społeczeństwa. Niezwykle interesujące tezy podjął prof. Waldemar Rezmer w swoim wystąpieniu: „O nowych formach i możliwościach kształcenia - o wojsku i dla wojska". Jego zdaniem zrozumiałe jest, iż w publicznej dyskusji dotyczącej bezpieczeństwa Rzeczypospolitej podniesiono m.in. problem szkolenia i przygotowywania rezerw ludzkich. Działania militarne, które toczą się na Ukrainie i inne dramatyczne wydarzenia na świecie, uświadomiły decydentom, że pokój nie jest dany raz na zawsze, że wciąż aktualna jest, sformułowana przez starożytnych Rzymian, reguła si vis pacem, para bellum, czyli jeżeli chcesz pokoju, gotuj się do wojny. Na postawione zebranym pytanie, czy potrzebny jest powrót do poboru powszechnego - zauważy1, że może warto pomyśleć o rekrutacji ochotniczej. Wobec wysokiego wciąż bezrobocia wśród młodych ludzi stworzenie np. systemu, w którym podczas szkolenia wojskowego młodzież mogłaby zdobywać dodatkowe kwalifikacje zawodowe, przydatne z jednej strony dla wojska, a z drugiej pozwalające podjąć satysfakcjonującą pracę $\mathrm{w}$ firmach cywilnych, mogłoby w jakimś stopniu rozwiązać problem. Ostatnim prelegentem był prof. Adam Suchoński, który odniósł się do kwestii militariów I wojny światowej na kartach wybranych, zagranicznych podręczników do nauczania historii. W bogatej w swe treści wypowiedzi profesor scharakteryzował możliwości podręcznikowego przekazu wiedzy historycznej, która zostaje siłą rzeczy zawężona do minimum. Uczeń po lekturze wybranych podręczników, 
gdzieś na poziomie gimnazjalnym lub licealnym, dowie się, że na potrzeby wojny pracowała gospodarka całej Europy i nie tylko Europy i najtęższe umysły zastanawiały się nad tym, jak udoskonalić sztukę wzajemnego zabijania się, że pojawiły się różne rodzaje broni, które do tej pory nie były w użyciu, np.: czołgi, łodzie podwodne, lotnictwo i in.; że rozwinęły się nowe rodzaje wojsk, np.: wojska chemiczne, wojska inżynierskie; że straciła na znaczeniu kawaleria, co nie znaczy, że już jej nie było, ale już nie odgrywała takiej roli, jak we wcześniejszych konfliktach zbrojnych. W podręcznikach nie ma jednak miejsca na refleksję nad istotą działań wojennych jako siły wyniszczającej cywilizację.

Podniesiona przez głównych prelegentów problematyka znalazła odbicie w ,żywej” dyskusji. Głos wiodący mieli w niej profesorowie: Karol Olejnik, Adam Suchoński, Marian Mroczko i Jerzy Przybylski. Należy w tym miejscu zauważyć, że nie zamknęła się ona tylko w gronie uczestników konferencji. Gośćmi oraz słuchaczami gwałtownych niejednokrotnie w swej wymowiepolemikbylibowiem licznie zgromadzeni uczniowie szkół średnich wybrzeża: Zespołu Szkół Ogólnokształcących z Redy, 9 Liceum Ogólnokształcącego i 1 Akademickiego Liceum Ogólnokształcącego z Gdyni. Dzięki temu konferencja miała - zgodnie z narzuconą ideą - samoistny walor edukacyjny.

Zakończenie pierwszej części sesji plenarnej nie zamknęło ożywienia naukowego, które wśród uczestników trwało także podczas zaplanowanego spaceru brzegiem morza do latarni morskiej w Rozewiu. Po zwiedzeniu Muzeum Latarnictwa Morskiego, w drugiej części konferencji zgromadzeni uczestnicy wysłuchali z uwagą obszernej wypowiedzi gościa specjalnego rozewskiego spotkania, wiceadm. dr. Stanisława Zarychty dowódcy Centrum Operacji Morskich, który mówił o współczesnej roli i zadaniach Marynarki Wojennej Rzeczypospolitej Polskiej.

Wystąpienie admirała zakończyło część plenarną konferencji. Po niej jej uczestnicy podjęli prawie trzygodzinne obrady w zespołach problemowych. Jak słusznie zauważył prof. Wiesław Wróblewski, który przewodniczył sesji plenarnej, treści poruszane $\mathrm{w}$ dotychczasowej dyskusji stanowiły swoistą prowokację intelektualną dla obrad popołudniowych. Tezy do dyskusji tworzyły podstawę rozważań w zespołach, ale w żaden sposób nie stanowiły ograniczania inicjatywy i aktywności osób zabierających głos. Pierwszy zespół podjął rozważania na temat: „Historia wojskowa wobec wyzwań współczesności”. Tematyka ta oscylowała wokół szeregu tez, z których najważniejsze to: kondycja historii w ogóle; rola Polskiego Towarzystwa Historycznego; ,polityka historyczna” i jej wpływ na kondycję dydaktyki i badań naukowych w dziedzinie historii; środowisko 
historyków wojskowych imożliwościach promowania dobrych doświadczeń dydaktycznych i naukowo-badawczych; potrzeba integracji środowiska na rzecz wzmocnienia jego głosu w sprawach rozwoju historii wojskowej; współczesny dyskurs historyczny - jego sukcesy i niepowodzenia oraz sposoby chrony i możliwości rozwoju dorobku polskiej historii wojskowej. Moderatorem tego panelu był dr Andrzej Drzewiecki.

Zespół drugi stanął przed odpowiedzią na pytanie: kogo i jak edukować wojskowo, militarnie, historycznie? Dyskutowano m.in. o kondycji dydaktyki historii; stosunku młodzieży do historii; przyczynach i następstwach ,upadku” historii; niszowych specjalnościach „historycznych”, zadając sobie pytanie, czy jest to droga do sukcesu, czy walka o przetrwanie; o bezdrożach animacji historii i „rekonstrukcjach” historycznych; jak edukować, po jakie środki wyrazu sięgać, jak „historycznie” aktywizować młodzież; a także na temat roli nauczyciela historii (kim jest, a kim powinien być, (stać się)); sposobu mówienia o wojsku i militariach, by nie budzić niepotrzebnych emocji; roli archiwów, muzeów, izby pamięci, skansenów w edukacji historycznej oraz współczesnego wychowania patriotycznego. Moderator panelu był prof. AMW dr hab. Piotr Semków.

Ciekawą tematykę podjął zespół trzeci, który dyskutował nad problematyką, Militariów, odtwórstwa i turystyki w edukacji historycznej”. Szukano odpowiedzi na szereg pytań: czym jest odtwórstwo i turystyka historyczna? jakim potencjałem (naukowym i popularyzatorskim) dysponuje rekonstrukcja historyczna? jakie są możliwe formy i treści przekazu historycznego na szlaku turystycznym? jak organizować i użytkować ścieżki i trasy turystyki historycznej? jak eksponować militaria na szlaku turystycznym? czym jest odtwórstwo historyczne - ile w nim rozrywki (przyjemności), a ile edukacji? jak budować programy studiów o specjalności odtwórstwo i turystyka historyczna? Moderatorem tego panelu był dr Mariusz Kardas.

Dyskusja prowadzona $\mathrm{w}$ zespołach miała wielokrotnie przebieg „burzliwy”, ale w swej merytoryce nie odbiegała od założonych przez organizatorów tematów. W jej trakcie padło wiele cierpkich słów, które jednak zawsze wyrażały troskę o słabnącą kondycję historii wśród innych nauk humanistycznych. Sformułowano wiele postulatów, które mogłyby przy uwzględnieniu ich przez decydentów - wesprzeć działania mające na celu rozwój historii w wielu wymiarach edukacyjnych. Należy w tym miejscu zauważyć, że całość dyskusji została zarejestrowana, celem wydania $\mathrm{w}$ formie suplementu, tj. tomu trzeciego jako wydawnictwo pokonferencyjne. 
Drugi dzień konferencji miał wymiar merytoryczno-poznawczy. Uczestnicy konferencji opuścili Rozewie, by w Gdyni zaokrętować się na okręt Marynarki Wojennej Rzeczypospolitej Polskiej ORP „Wodnik”. Rejs w formule podróży historyczno-morskiej nawiązywał do tematyki konferencji, gdyż został przygotowany w obszarze problematyki „Militariów nadbrzeżnych z morza widzianych". Uczestnicy rejsu mieli możliwość spojrzeć w nietypowy sposób na nadmorskie pola bitew II wojny światowej, tj. Hel, Westerplatte i Gdynię. Zapoznali się również z fragmentami ceremoniału morskiego Marynarki Wojennej. Po wyokrętowaniu nastąpił powrót do Rozewia, gdzie oficjalnie konferencja została zakończona.

Podsumowując, spotkanie w Rozewiu nie było w żadnym wypadku sądem nad stanem historii, instytucjami i stowarzyszeniami sprzyjającymi edukacji i badaniom historycznym. Było swoistym refleksyjnym „pochyleniem się” nad historią wojskową, w obszarze nauki historycznej. W trakcie rozlicznych, wielowymiarowych dyskusji starano się wydobyć z bogactwa nauki historycznej kwestie wojskowości, by spojrzeć na nie jako na przedmiot edukacji. Zgodzono się, że są one tą częścią historii, która pozwala nam sądzić o kulturze danego społeczeństwa. Podczas sesji plenarnej został sformułowany pogląd, by na historię wojskową patrzeć z różnych perspektyw, m.in.: politycznej i ideologicznej, społecznej i gospodarczej, a także kulturowej, geograficznej, demograficznej czy psychologicznej. Dostrzeżono płynące zagrożenia ze źle zdefiniowanej tzw. polityki historycznej państwa. Pozytywne jest to, że młodzi ludzie coraz liczniej interesują się historią wojskową, zwłaszcza w jej rekonstrukcyjnym wymiarze. Ten popularyzatorski kierunek edukacji przyczynia się do wzrostu świadomości historycznej. Podczas dyskusji panelowych stwierdzono jednak, że nie ma prostej zależności, z której wynikałoby, że liczebność grup rekonstrukcyjnych przekłada się na wiedzę i samoświadomość historyczną. Funkcjonują one bowiem na ogół poza akademickim systemem edukacji historycznej.

Gwoli ścisłości, należy na koniec dodać, że konferencję zrealizowano i dofinansowano z funduszu „Narodowego programu rozwoju humanistyki”, w ramach projektu badawczego zatytułowanego: „Inwentaryzacja zabytków militarnych na Pomorzu (XIX i XX wiek) oraz ich wykorzystanie w działalności dydaktycznej i turystyce historycznej”. Donatorami wydawnictwa były: Miasto Gdynia, Urząd Miasta Helu i Gmina Puck. Uczestnicy tego naukowego spotkania korzystali z gościnności firmy Okulski Grand z siedzibą w Rozewiu. 